\title{
Pengaruh Variasi Fotoperiodisitas terhadap Pertumbuhan Chlorella dalam Medium Basal Bold
}

\author{
Photoperiodicity effect on Chlorella Growth in Bold's Basal Medium \\ Nining B. Prihantini*, Winny Rachmayanti, Wisnu Wardhana \\ Departemen Biologi Fakultas Matematika dan Ilmu Pengetahuan Alam \\ Universitas Indonesia, Kampus UI Depok 16424 \\ Telp.+62-21-78849009 E-mail: nprihantini@hotmail.com,nining@ui.edu
}

\begin{abstract}
The research of photoperiodicity effect on the cell densities of genus Chlorella grown in Bold's Basal Medium (BBM) had been done. Observations were done for 14 days. Research was experimental study with full random design to 8 varieties of photoperiodicity i.e. $6 \mathrm{~h}$ light/18 h dark (L/D) cycles, 8 h light/16 h dark (L/D) cycles, $10 \mathrm{~h}$ light/14 h dark (L/D) cycles, $12 \mathrm{~h}$ light/12 h dark (L/D) cycles, $14 \mathrm{~h}$ light/10 h dark (L/D) cycles, $16 \mathrm{~h}$ light/8 h dark (L/D) cycles, $18 \mathrm{~h}$ light/6 h dark (L/D) cycles, and $24 \mathrm{~h} \mathrm{light/0} \mathrm{h}$ dark (L/D) cycles. On peak culture, $24 \mathrm{~h}$ light/0 h dark (L/D) cycles produced the highest cell numbers $(204.680 .000 \mathrm{cell} / \mathrm{ml})$ and the lowest cell numbers were achieved by culture with $6 \mathrm{~h}$ light/18 h dark (L/D) cycles. Kruskall-Wallis test showed that there were some effects of photoperiodicity variations on cell numbers of Chlorella (cell/ml) in culture (p>0.05). Multiple comparison tests showed that mean of cell numbers of Chlorella (cell/ml) differ (p>0.01) on every photoperiodicity. Relationship between photoperiodicity and cell numbers of Chlorella was determined by regression equation $\hat{Y}=24634821,214+$ 21977643,869 X.
\end{abstract}

Key Words: Chlorella, Photoperiodicity, algal physiology

Diterima: 04 Mei 2005, disetujui: 20 Juni 2006

\section{Pendahuluan}

Sebagai salah satu sumberdaya hayati, mikroalga mempunyai beragam potensi yang telah lama dimanfaatkan oleh manusia. Potensi tersebut, antara lain sebagai; a) pakan alami berbagai jenis ikan, udang, kerang, b) bahan pangan nonkonvensional, c) bahan baku dalam industri kimia dan farmasi, d) penghasil sumber energi (gas $\mathrm{H}_{2}$, alkohol, dan hidrokarbon siklis), e) pupuk hayati (Kabinawa, 1993). Mikroalga juga dapat berperan sebagai indikator pencemaran perairan dan agen bioremidiasi limbah cair (Lee \& Lee, 2001).

Salah satu mikroalga yang potensial dan telah umum dibiakkan adalah marga Chlorella Beijerinck. Hal tersebut disebabkan Chlorella memiliki kandungan gizi yang tinggi, yaitu
$50 \%$ protein, $20 \%$ karbohidrat, dan $20 \%$ lemak. Selain itu, Chlorella juga mengandung berbagai nutrisi seperti asam lemak tidak jenuh, vitamin, klorofil, enzim, serat, dan CGF (Chlorella Growth Factor) (Wirosaputro, 1998).

Chlorella juga banyak digunakan sebagai objek penelitian fisiologi dan biokimia karena mudah dibiakkan. Chlorella dapat tumbuh cepat dalam waktu yang relatif singkat (Pandey \& Trivedi, 1995). Menurut Sachlan (1982), satu sel Chlorella dapat berkembang menjadi 10.000 sel dalam waktu 24 jam. Burlew pada tahun 1953 (dalam Kabinawa et al., 1993) menyatakan bahwa Chlorella merupakan mikroalga pertama yang berhasil dibiakkan dalam medium dan kondisi lingkungan tertentu. Pada tahun 1988 Pauw \& Guino (dalam Agustini \& Kabinawa, 1993) 
menyatakan bahwa Chorella telah berhasil dibiakkan dalam akuakultur dan mudah tumbuh dalam medium sintetik anorganik.

Chlorella dapat dikembangkan melalui teknik kultur, meskipun demikian dalam pengembangannya masih menghadapi kendala, yaitu rendahnya produksi biomassa (Chrismadha dkk., 1998). Brown pada tahun 1991 (dalam Hadiwigeno dkk., 1993) menyatakan bahwa upaya untuk meningkatkan produksi biomassa Chlorella dapat dilakukan dengan memanipulasi lingkungan hidupnya seperti medium, intensitas dan panjang gelombang cahaya, lama penyinaran (fotoperiodisitas), kadar $\mathrm{CO}_{2}$, suhu, $\mathrm{pH}$, salinitas, serta bentuk wadah kultur.

Pengetahuan mengenai respon pertumbuhan Chlorella terhadap faktor lingkungan tertentu dapat dijadikan dasar untuk menentukan kondisi lingkungan yang optimum dalam teknik kultur massal. Salah satu faktor lingkungan yang sangat berpengaruh terhadap pertumbuhan dan produktivitas Chlorella adalah lama penyinaran (fotoperiodisitas) yang diberikan kepada kultur (Lorenzen, 1964). Fotoperiodisitas yang diberikan kepada kultur Chlorella di laboratorium biasanya bertujuan untuk mendapatkan sinkronisasi kultur yang kemudian digunakan untuk mempelajari siklus sel mikroalga tersebut (Hase, 1962; Lorenzen, 1964; Fogg \& Thake, 1987).

Pemberian fotoperiodisitas yang tepat terhadap kultur Chlorella diharapkan dapat memberikan hasil produksi biomassa yang tinggi. Berdasarkan hal tersebut, maka perlu dilakukan penelitian mengenai pertumbuhan mikroalga marga Chlorella Beijerinck dengan parameter rerata kerapatan sel dalam Medium Basal Bold (MBB) menggunakan variasi fotoperiodisitas. Penelitian ini bertujuan untuk mengetahui fotoperiodisitas yang optimum bagi kerapatan sel mikroalga marga Chlorella Beijerinck dalam MBB selama 14 hari pengamatan.

\section{Metode Penelitian}

\section{Lokasi dan Waktu Penelitian}

Penelitian dilakukan di ruang kultur alga, Laboratorium Taksonomi Tumbuhan Biota Vol. 12 (1), Februari 2007
Departemen Biologi FMIPA-UI pada bulan Juli sampai dengan Agustus 2004.

\section{Bahan dan Cara Kerja}

Sampel kultur Chlorella yang digunakan berasal dari koleksi Laboratorium Taksonomi Tumbuhan Departemen Biologi FMIPA-UI yang merupakan hasil isolasi dari tanah di Depok. Sedangkan medium yang digunakan sebagai medium kultur pemeliharaan dan perlakuan adalah Medium Basal Bold (Nichols, 1973).

Penelitian bersifat eksperimental menggunakan rancangan acak lengkap (RAL) yang terdiri dari delapan macam perlakuan dan tiga ulangan untuk setiap perlakuan. Perlakuan yang dimaksud adalah sebagai berikut: penyinaran 6 jam terang/ 18 jam gelap (6T/ $18 \mathrm{G}), 8$ jam terang/ 16 jam gelap (8T/ $16 \mathrm{G}), 10$ jam terang/ 14 jam gelap (10T/ 14G), 12 jam terang/ 12 jam gelap (12T/ 12G), 14 jam terang/ 10 jam gelap (14T/ 10G), 16 jam terang/ 8 jam gelap (16T/ 8G), 18 jam terang/ 6 jam gelap (18T/ 6G), dan 24 jam terang/ 0 jam gelap (24T/ 0G).

Sebanyak $10 \mathrm{ml}$ kultur Chlorella berkerapatan $15.000 .000 \mathrm{sel} / \mathrm{ml}$ diinokulasikan ke dalam $300 \mathrm{ml}$ medium perlakuan. Pemeliharaan kultur perlakuan Chlorella dilakukan selama 14 hari. Hal tersebut didasarkan pada hasil penelitian pendahuluan yang menunjukkan bahwa dalam kurun waktu 14 hari kultur Chlorella telah memasuki fase stasioner. Kultur perlakuan diletakkan di dalam rak kultur tertutup dan masing-masing diberi aerasi menggunakan aerator akuarium berlubang satu. Rak kultur berukuran panjang $92 \mathrm{Cm}$, lebar $31 \mathrm{Cm}$, dan tinggi $41 \mathrm{Cm}$. Satu buah lampu TL berkekuatan 20 watt dengan rerata intensitas cahaya sebesar 1500 lux digunakan untuk pencahayaan. Lampu diletakkan sejajar di sisi belakang rak kultur dengan jarak 7,5 cm dari botol kultur. Panjang lampu $62 \mathrm{Cm}$, sedangkan banyak botol kultur untuk setiap perlakuan adalah 3 botol. Pengaturan lama penyinaran (fotoperiodisitas) bagi masing-masing perlakuan dilakukan menggunakan pengatur waktu (timer) elektronik secara otomatis.

Penghitungan jumlah sel Chlorella dilakukan secara berkala setiap 24 jam sekali 
mulai hari ke-0 ( $\left.\mathrm{t}_{0}\right)$ hingga hari ke-14 $\left(\mathrm{t}_{14}\right)$. Penghitungan jumlah sel dilakukan di bawah mikroskop menggunakan kamar hitung Improved Neubauer. Jumlah sel dihitung menggunakan empat kotak besar yang terletak di sudut luar dengan tanda W (white). Data jumlah sel yang diperoleh tersebut selanjutnya digunakan untuk menghitung kerapatan sel. Kerapatan sel Chlorella dalam $1 \mathrm{ml}$ sampel dihitung dengan rumus $\mathrm{k}=\mathrm{n} \times \mathrm{p} \times 2500$, dengan $\mathrm{k}=$ kerapatan sel Chlorella $(\mathrm{sel} / \mathrm{ml}), \mathrm{n}$ $=$ jumlah total sel dalam empat kotak kamar hitung Improved Neubauer, dan $\mathrm{p}$ adalah tingkat pengenceran yang digunakan (Adil, 2002).

Kadar klorofil kultur perlakuan Chlorella diukur menggunakan metode Vonshak 1990 (dalam Hendrayanti, 1995) yang telah dimodifikasi. Sebanyak $10 \mathrm{ml}$ sampel kultur perlakuan dimasukkan ke dalam tabung sentrifus, kemudian disentrifugasi dengan kecepatan $5000 \mathrm{rpm}$ selama 10 menit. Supernatan dibuang sedangkan endapannya diambil. Endapan biomassa sel Chlorella ditambahkan aseton 90\% sehingga volume akhir menjadi $10 \mathrm{ml}$, kemudian dimassukkan beberapa butir glass bead untuk memecah dinding sel Chlorella. Suspensi tersebut kemudian divorteks selama 20 menit dan disentrifugasi kembali dengan kecepatan 1000 rpm selama 5 menit. Supernatan diambil untuk diperiksa menggunakan spektrofotometer pada panjang gelombang 663 dan $645 \mathrm{~nm}$, sedangkan endpannya dibuang. Nilai absorbansi yang didapat kemudian dimasukkan ke dalam rumus penghitungan kadar klorofil berdasarkan Meeks (1974), yaitu Total klorofil $(\mathrm{mg} / \mathrm{l})=20,2 \lambda_{645 \mathrm{~nm}}+8,02$ $\lambda_{663 \mathrm{~nm}}$; Klorofil a $(\mathrm{mg} / \mathrm{l})=12,7 \lambda_{663 \mathrm{~nm}}-2,69$ $\lambda_{645 \mathrm{~nm}}$; Klorofil b $(\mathrm{mg} / \mathrm{l})=22,9 \lambda_{645 \mathrm{~nm}}-4,64$ $\lambda_{663 \mathrm{~nm}}$.

\section{Hasil dan Pembahasan}

\section{Kurva Pertumbuhan}

Kurva pertumbuhan Chlorella dalam BBM dengan variasi fotoperiodisitas selama 14 hari pengamatan disajikan dalam bentuk grafik transformasi rerata kerapatan sel $(\log \mathrm{x})$ (Gambar 1). Kurva pertumbuhan Chlorella pada masing-masing perlakuan menunjukkan pola yang hampir sama, hanya terdapat perbedaan dalam waktu dan kerapatan sel yang dicapai pada saat peak. Pola kurva pertumbuhan tersebut dapat digunakan untuk menentukan fase-fase yang dialami oleh kultur Chlorella.

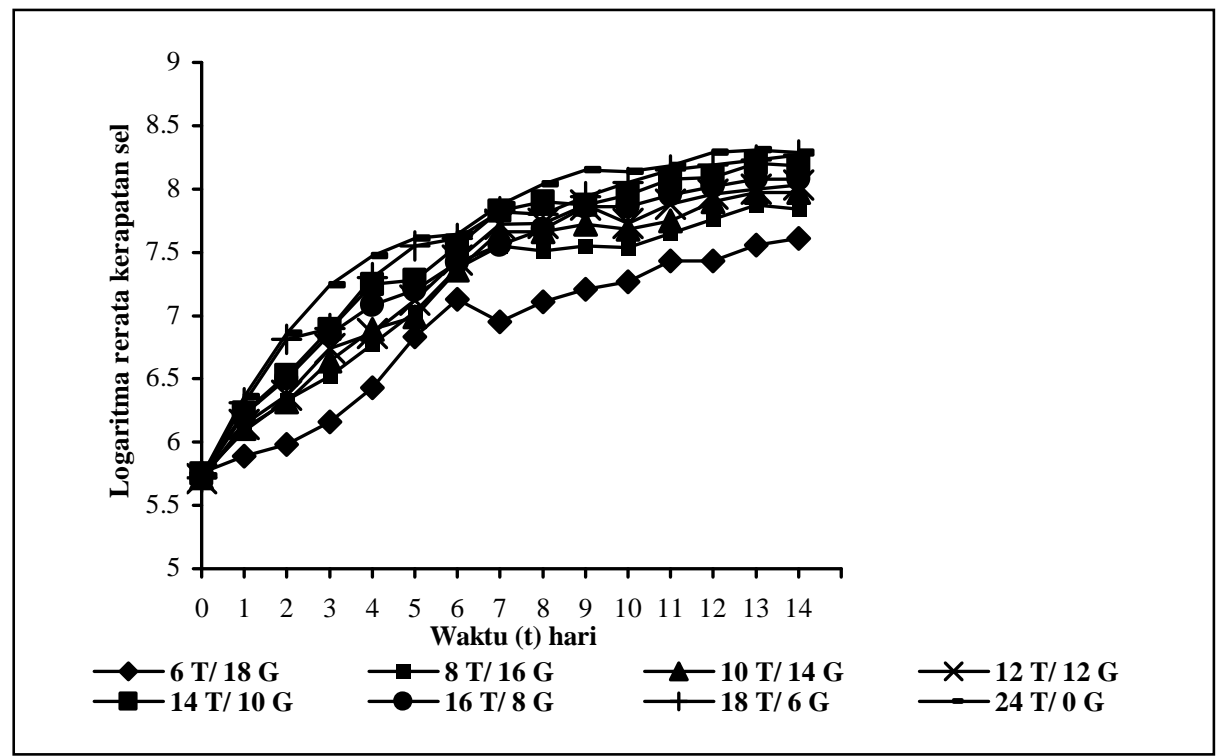

Gambar 1. Rerata kerapatan sel mikroalga marga Chlorella dalam Medium Basal Bold dengan variasi fotoperiodisitas selama 14 hari pengamatan 
Pola kurva pertumbuhan Chlorella pada semua perlakuan fotoperiodisitas tidak memperlihatkan adanya fase adaptasi. Pengamatan yang dilakukan 24 jam setelah inokulasi menunjukkan terjadinya peningkatan kerapatan sel pada semua perlakuan (Gambar 1). Hal tersebut dapat terjadi karena pada waktu pengamatan (24 jam setelah inokulasi) fase adaptasi kemungkinan telah terlewati.

Medium kultur dan kondisi lingkungan yang digunakan kemungkinan berpengaruh terhadap lama fase adaptasi. Penggunaan media kultur (MBB) dan kondisi lingkungan yang sama seperti pemeliharaan kultur sebelumnya memungkinkan sel-sel mikroalga yang diinokulasikan mampu bertahan hidup dan berada dalam kondisi siap untuk melakukan pembelahan sel. Inokulasi sejumlah sel-sel mikroorganisme, termasuk mikroalga, ke dalam media dan kondisi lingkungan yang sama seperti pada pemeliharaan kultur sebelumnya menyebabkan tidak terlihatnya fase adaptasi dan fase eksponensial segera berlangsung (Madigan et al., 1997).

Fase eksponensial pada semua perlakuan mulai terlihat pada hari ke-1 hingga hari ke-13 (Gambar 1). Proses perbanyakan sel Chlorella selama fase eksponensial berlangsung sangat cepat sehingga menghasilkan pertambahan populasi yang sangat cepat pula. Pertambahan populasi sel Chlorella yang sangat cepat tersebut kemungkinan terjadi karena terciptanya kondisi lingkungan yang sesuai bagi pertumbuhan Chlorella. Kebutuhan nutrien sel Chlorella dapat dipenuhi melalui penggunaan MBB sebagai media kultur. Cahaya yang dibutuhkan dalam proses fotosintesis dapat dipenuhi oleh penggunaan sumber cahaya dengan intensitas yang sesuai (1500 lux) meskipun dengan pemberian fotoperiodisitas yang berbeda-beda.

Setelah mencapai puncak, pada kurva pertumbuhan terlihat adanya penurunan rerata kerapatan sel yang tidak signifikan (Gambar 1). Hal tersebut dapat dilihat pada kultur dengan pemberian fotoperiodisitas $8 \mathrm{~T} / 16 \mathrm{G}, 14 \mathrm{~T} / 10$ G, 16 T/ 8 G, dan 24 T/ 0 G. Penurunan rerata kerapatan sel belum terlihat pada keempat kultur perlakuan lainnya (fotoperiodisitas $6 \mathrm{~T} /$ $18 \mathrm{G}, 10 \mathrm{~T} / 14 \mathrm{G}, 12 \mathrm{~T} / 12 \mathrm{G}$, dan $18 \mathrm{~T} / 6 \mathrm{G})$ namun pertambahan kerapatan sel yang signifikan sudah tidak lagi terjadi. Kedua hal tersebut menandakan bahwa semua kultur perlakuan mulai memasuki fase stasioner. Fase stasioner ditandai dengan tidak adanya pertambahan maupun pengurangan kerapatan sel secara signifikan (Madigan et al., 1997).

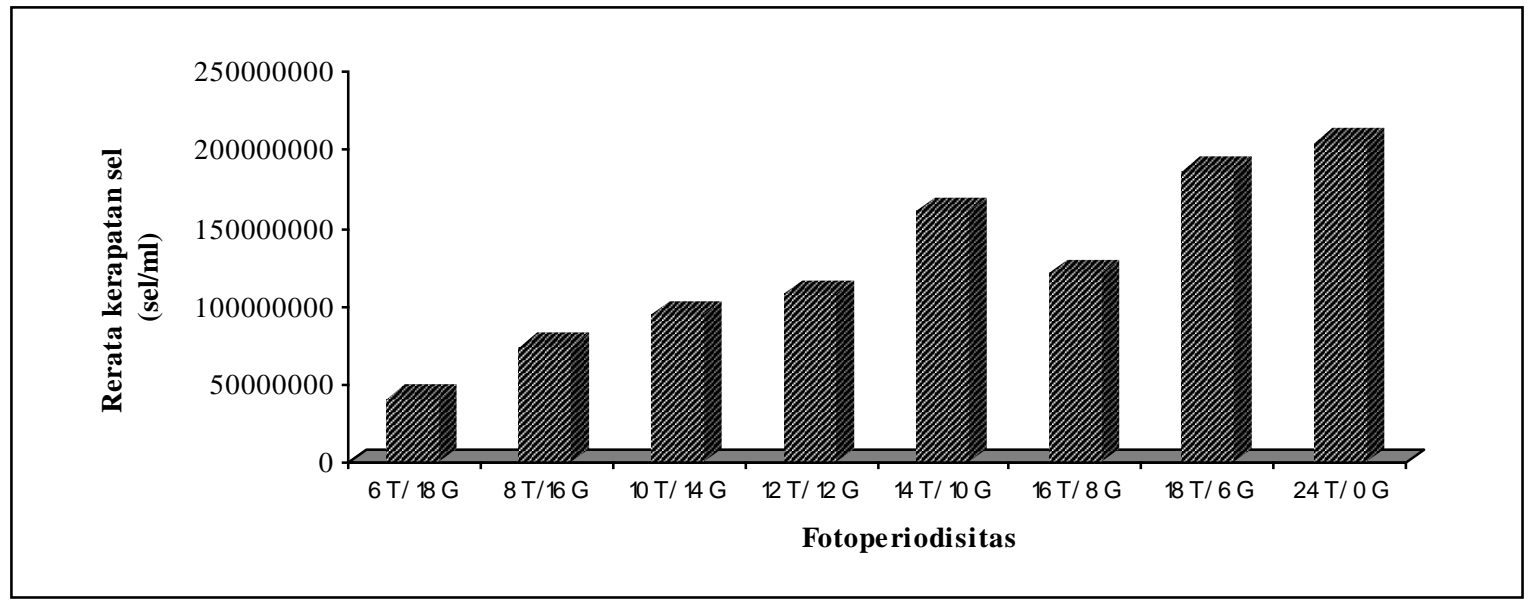

Gambar 2. Rerata kerapatan sel Chlorella dalam Medium Basal Bold pada saat peak dengan berbagai variasi fotoperiodisitas 
Pencapaian fase stasioner oleh suatu
kultur mikroalga berkaitan dengan
berkurangnya sejumlah besar nutrien dalam
media kultur dan terjadinya mekanisme
autoinhibisi (Fogg \& Thake, 1987). Berkurangnya ketersediaan nutrien seperti nitrat dan besi dapat menjadi faktor pembatas pertumbuhan (Fogg \& Thake, 1987). Mekanisme autoinhibisi dapat terjadi karena akumulasi berlebih senyawa-senyawa sisa metabolisme yang dihasilkan oleh sel-sel mikroalga. Apabila mekanisme autoinhibisi terjadi dalam suatu kultur mikroalga, maka pertumbuhan akan berhenti saat mencapai kerapatan sel tertentu (Fogg \& Thake,1987).

Penurunan kerapatan sel juga dapat disebabkan berkurangnya intensitas cahaya yang dapat diterima oleh sel Chlorella akibat adanya fenomena pembentukan bayangan oleh sel-sel mikroalga tersebut dalam kultur (selfshading). Fenomena tersebut terjadi karena kultur semakin padat, sehingga hanya sel-sel yang berada di permukaan (sisi atas dan samping botol kultur) saja yang dapat menerima cahaya dalam jumlah yang cukup (Fogg \& Thake 1987). Sel-sel yang berada di bagian lebih dalam menjadi kekurangan cahaya yang dibutuhkan dalam proses fotosintesis sehingga metabolisme sel berjalan lebih lambat dan pada akhirnya berpengaruh terhadap kerapatan sel (Reynolds, 1984; Fogg \& Thake 1987).

\section{Kerapatan sel}

Rerata kerapatan sel Chlorella pada saat inokulasi berkisar antara 517.778-569.722 sel/ml. Rerata kerapatan sel Chlorella pada saat peak (puncak) ditunjukkan pada Gambar 2.

Berdasarkan hasil penghitungan, rerata kerapatan sel setelah inokulasi meningkat pada semua perlakuan fotoperiodisitas. Peningkatan rerata kerapatan sel Chlorella $(\mathrm{sel} / \mathrm{ml})$ pada kedelapan kultur perlakuan menunjukkan adanya pemanfaatan energi cahaya bagi pertumbuhan mikroalga tersebut. Cahaya merupakan faktor utama dalam proses fotosintesis yang dilakukan oleh sel-sel Chlorella. Cahaya diserap oleh pigmen-pigmen fotosintetik yang terdapat di dalam kloroplas kemudian diubah menjadi energi kimia dalam bentuk ATP dan NADPH melalui reaksi terang. Energi kimia tersebut kemudian digunakan untuk mereduksi karbondioksida $\left(\mathrm{CO}_{2}\right)$ menjadi senyawa-senyawa organik melalui reaksi gelap (Sze, 1993; Madigan et al., 1997). Senyawa-senyawa organik yang dihasilkan melalui proses fotosintesis adalah glukosa, lemak, asam amino, dan asam karboksilat (Clegg \& Mackean, 2000). Senyawa organik tersebut antara lain berperan sebagai senyawa pembangun (building blocks) komponen-komponen sel Chlorella.

Sebagai salah satu produk fotosintesis, glukosa merupakan senyawa karbon organik esensial bagi pertumbuhan sel Chlorella. Glukosa dapat langsung diuraikan melalui proses respirasi dan dapat pula disimpan dalam bentuk pati sebagai cadangan energi. Penguraian glukosa melalui proses respirasi akan menghasilkan energi dalam bentuk ATP. Energi tersebut kemudian digunakan untuk menyintesis senyawa-senyawa makromolekul lain serta berperan dalam berbagai reaksi metabolisme yang mendukung proses pertumbuhan dan pembelahan sel, sehingga pada akhirnya akan meningkatkan kerapatan sel.

Pemberian variasi fotoperiodisitas terhadap kultur Chlorella ternyata memberikan hasil kerapatan sel ( $\mathrm{sel} / \mathrm{ml})$ yang berbeda-beda. Hal tersebut ditegaskan oleh hasil uji KruskallWallis terhadap data rerata kerapatan sel selama 14 hari pengamatan yang menunjukkan adanya pengaruh variasi fotoperiodisitas terhadap kerapatan sel Chlorella. Selain itu, hasil uji perbandingan berganda terhadap data rerata kerapatan sel selama 14 hari pengamatan menunjukkan adanya perbedaan yang sangat nyata $(\mathrm{p}>0,01)$ antarperlakuan.

Hasil kerapatan sel (sel/ml) yang berbeda-beda tersebut disebabkan oleh perbedaan lama periode terang dan gelap yang diberikan kepada kultur. Periode terang yang diberikan kepada masing-masing kultur perlakuan $(6,8,10,12,14,16,18$, dan 24 jam) berpengaruh terhadap dua tahap awal yang terjadi selama siklus hidup sel Chlorella, yaitu tahap pertumbuhan (growth phase) dan tahap pematangan awal (early ripening phase). Kedua tahap tersebut hanya akan terjadi bila tersedia cahaya dalam jumlah yang mencukupi.

Biota Vol. 12 (1), Februari 2007 
Selama tahap pertumbuhan (growth phase) berlangsung, ketersediaan cahaya dimanfaatkan oleh sel Chlorella untuk berfotosintesis dengan aktif sehingga menghasilkan peningkatan ukuran autospora. Selain itu, ketersediaan cahaya untuk proses fotosintesis juga dibutuhkan oleh sel Chlorella dalam mempersiapkan proses pembelahan sel (tahap pematangan awal/ early ripening phase). Periode gelap yang diberikan kepada kultur berperan dalam proses pembelahan sel (Lorenzen 1964; Kaftan et al., 1999).

Hasil penghitungan rerata kerapatan sel menunjukkan bahwa peningkatan rerata kerapatan sel Chlorella pada saat peak (puncak) berbanding lurus dengan peningkatan lama pemberian periode terang pada kultur. Hal tersebut ditegaskan oleh persamaan regresi linier sebagai berikut: $\hat{Y}=24634821,214+$ 21977643,869 X, dimana Y adalah kepadatan sel dan $\mathrm{X}$ adalah fotoperiodesitas. Kepadatan sel tergantung pada fotoperiodesitas sebesar a $\mathrm{X}+\mathrm{b}$. Pengecualian terjadi pada kultur dengan pemberian fotoperiodisitas $14 \mathrm{~T} / 10 \mathrm{G}$ yang memiliki kerapatan sel pada saat peak lebih tinggi $(160.140 .000 \mathrm{sel} / \mathrm{ml})$ dibanding kultur dengan pemberian fotoperiodisitas $16 \mathrm{~T} / 8 \mathrm{G}$ (121.040.000 sel $/ \mathrm{ml})$. Kultur dengan pemberian periode terang 16 jam lebih lama daripada kultur dengan pemberian periode terang 14 jam, meskipun demikian kepadatan sel dari kultur (16 jam terang) lebih rendah.

Semakin lama periode terang yang diberikan kepada kultur akan menyebabkan peningkatan kapasitas fotosintesis. Hal tersebut berpengaruh terhadap energi yang dihasilkan untuk melakukan proses pertumbuhan dan persiapan pembelahan sel (Clegg \& Mackean, 2000). Oleh karena itu, semakin lama periode terang yang diberikan kepada kultur akan menghasilkan kerapatan sel (sel/ml) yang semakin tinggi.

Pemberian periode terang secara kontinu (24 T/ 0 G) pada kultur Chlorella menghasilkan rerata kerapatan sel tertinggi saat peak, yaitu sebesar 204.680.000 sel/ml. Hal itu disebabkan kultur dengan pemberian fotoperiodisitas $24 \mathrm{~T} / 0$ $\mathrm{G}$ memiliki kapasitas fotosintesis tertinggi dibanding kultur perlakuan lainnya. Sel-sel Chlorella pada kultur tersebut menghasilkan lebih banyak energi yang tersimpan dalam bentuk senyawa karbon organik esensial (glukosa). Energi tersebut digunakan oleh sel-sel Chlorella untuk melakukan proses pertumbuhan dan pembelahan sel. Pemberian periode terang secara kontinu menyebabkan autospora yang dihasilkan oleh sel induk akan mulai berfotosintesis dengan aktif dan siap memulai siklus hidup berikutnya.

Kerapatan sel yang tinggi pada kultur dengan pemberian fotoperiodisitas $24 \mathrm{~T} / 0 \mathrm{G}$ ternyata tidak didukung oleh kualitas selnya. Pengamatan yang dilakukan pada hari ke-14 menunjukkan bahwa sel-sel Chlorella pada kultur tersebut kurang berwarna hijau dibandingkan selsel perlakuan lainnya. Hasil pengukuran kadar klorofil pada kultur tersebut juga memberikan hasil yang paling rendah (Tabel 1). Hal tersebut diduga berkaitan dengan berkurangnya sejumlah besar nutrien dalam medium kultur, terutama unsur nitrogen $(\mathrm{N})$. Pemberian periode terang secara kontinu kemungkinan berpengaruh terhadap peningkatan penyerapan sumber nitrogen dalam medium kultur oleh sel Chlorella. Penyerapan nitrat dan nitrit tergantung pada ketersediaan cahaya dan berkaitan dengan aktivitas fotosistem II di dalam kloroplas (Soeder \& Stengel, 1974). Nitrogen (N) merupakan salah satu komponen penyusun klorofil. Apabila kultur mengalami defisiensi unsur tersebut maka proses sintesis klorofil akan terganggu dan mengakibatkan penurunan kandungan klorofil sel Chlorella.

Tabel 1. Kadar klorofil total, klorofil a, dan klorofil b tiap perlakuan pada hari ke-14 pengamatan

\begin{tabular}{cccc}
\hline \hline Variasi fotoperiodisitas & Total klorofil $(\mathbf{m g} / \mathbf{l})$ & Klorofil a $(\mathbf{m g} / \mathbf{l})$ & Klorofil b $(\mathbf{m g} / \mathbf{l})$ \\
\hline \hline $6 \mathrm{~T} / 18 \mathrm{G}$ & 3,04064 & 1,20032 & 2,18372 \\
$8 \mathrm{~T} / 16 \mathrm{G}$ & 3,01332 & 1,30686 & 2,37246 \\
$10 \mathrm{~T} / 14 \mathrm{G}$ & 3,29582 & 1,44581 & 2,62406 \\
$12 \mathrm{~T} / 12 \mathrm{G}$ & 3,13452 & 1,38306 & 2,50986 \\
$14 \mathrm{~T} / 10 \mathrm{G}$ & 3,41702 & 1,52201 & 2,76146 \\
$16 \mathrm{~T} / 8 \mathrm{G}$ & 3,54534 & 1,47897 & 2,68722 \\
$18 \mathrm{~T} / 6 \mathrm{G}$ & 3,30294 & 1,32657 & 2,41242 \\
$24 \mathrm{~T} / 0 \mathrm{G}$ & 2,66992 & 1,09096 & 1,98316 \\
\hline \hline
\end{tabular}

Biota Vol. 12 (1), Februari 2007 
Kultur Chlorella dengan pemberian periode terang-gelap $(6 \mathrm{~T} / 18 \mathrm{G}, 8 \mathrm{~T} / 16 \mathrm{G}, 10$ $\mathrm{T} / 14 \mathrm{G}, 12 \mathrm{~T} / 12 \mathrm{G}, 14 \mathrm{~T} / 10 \mathrm{G}, 16 \mathrm{~T} / 8 \mathrm{G}, 18$ $\mathrm{T} / 6 \mathrm{G})$ ternyata memberikan hasil kerapatan sel (sel/ml) yang lebih rendah dibanding kultur dengan pemberian periode terang secara kontinu. Kerapatan sel Chlorella (sel/ml) semakin rendah seiring dengan semakin lama periode gelap yang diberikan kepada kultur.

Periode gelap yang diberikan pada kultur mengakibatkan terjadinya penurunan kapasitas fotosintesis. Reaksi terang dalam proses fotosintesis tidak akan terjadi dalam kondisi gelap, namun proses respirasi akan terus berlangsung. Hal tersebut kemungkinan menyebabkan jumlah $\mathrm{CO}_{2}$ yang dihasilkan melalui respirasi lebih besar daripada jumlah yang digunakan untuk fotosintesis. Sejumlah $\mathrm{CO}_{2}$ akan dilepaskan ke luar sel Chlorella dalam kondisi gelap melalui proses respirasi tanpa digunakan kembali oleh sel tersebut (Clegg \& Mackean, 2000). Semakin lama periode gelap yang diberikan kepada kultur maka akan semakin banyak $\mathrm{CO}_{2}$ yang dilepaskan ke luar sel, sedangkan senyawa karbon organik esensial (glukosa) yang dibentuk semakin sedikit. Oleh karena itu, semakin lama periode gelap yang diberikan kepada kultur maka akan semakin sedikit energi yang dapat digunakan untuk proses pertumbuhan dan pembelahan sel Chlorella.(Perlu dibentuk data pendukung ( $\mathrm{CO}_{2}$ dan glukosa)

Pemberian periode terang-gelap pada kultur Chlorella juga menyebabkan pengurangan biomassa sel. Hal tersebut disebabkan hilangnya sejumlah biomassa sel dalam keadaan gelap melalui proses respirasi (Lee \& Lee, 2001). Sel Chlorella akan menggunakan komposisi biokimia selnya dalam proses metabolisme untuk mendapatkan energi dalam keadaan tanpa cahaya (periode gelap). Hal tersebut akan menyebabkan penurunan berat sel (Ogbonna et al, 1999). Oleh karena itu, semakin lama periode gelap yang diberikan kepada kultur Chlorella maka jumlah biomassa yang hilang dalam keadaan gelap juga akan semakin besar. Hal tersebut kemungkinan menyebabkan semakin lama periode gelap yang diberikan kepada kultur
Chlorella akan memberikan hasil kerapatan sel (sel/ml) yang semakin rendah.

\begin{tabular}{cccc} 
Kultur & \multicolumn{2}{c}{ dengan } & pemberian \\
fotoperiodisitas & 14 & $\mathrm{~T} /$ & $10 \mathrm{G}$ ternyata
\end{tabular} menghasilkan kerapatan sel pada saat peak yang lebih tinggi $(160.140 .000 \mathrm{sel} / \mathrm{ml})$ dibanding kultur dengan pemberian fotoperiodisitas $\quad 16 \quad \mathrm{~T} / \quad 8 \quad \mathrm{G} \quad(121.040 .000$ $\mathrm{sel} / \mathrm{ml}$ ), namun tetap lebih rendah dibanding kultur dengan pemberian fotoperiodisitas $18 \mathrm{~T} /$ $6 \mathrm{G}(186.468 .750 \mathrm{sel} / \mathrm{ml})$ dan $24 \mathrm{~T} / 0 \mathrm{G}$ (204.680.000 sel $/ \mathrm{ml}$ ). Pemberian fotoperiodisitas $14 \mathrm{~T} / 10 \mathrm{G}$ digunakan dalam pemeliharaan kultur koleksi Chlorella hasil isolasi dari tanah di Depok. Pemberian fotoperiodisitas yang sama seperti saat pemeliharaan kultur koleksi kemungkinan menyebabkan kultur Chlorella telah beradaptasi dengan baik pada fotoperiodisitas tersebut.

\section{Kesimpulan}

Berdasarkan hasil penelitian dapat disimpulkan bahwa fotoperiodisitas berpengaruh terhadap kerapatan sel mikroalga marga Chlorella Beijerinck yang ditumbuhkan dalam Medium Basal Bold (MBB). Semakin lama periode terang diberikan kepada kultur perlakuan, kerapatan sel semakin meningkat. Fotoperiodisitas optimum bagi kerapatan sel mikroalga marga Chlorella Beijerinck dalam MBB selama 14 hari pengamatan adalah $24 \mathrm{~T} /$ 0 G. Fotoperiodisitas tersebut menghasilkan kerapatan sel tertinggi (204.680.000 sel $/ \mathrm{ml})$ pada saat peak. Kadar klorofil yang tertinggi $(3,54534 \mathrm{mg} / \mathrm{l})$ pada pengamatan hari ke-14 dicapai oleh kultur dengan pemberian fotoperiodisitas $16 \mathrm{~T} / 8 \mathrm{G}$, sedangkan kadar klorofil yang terendah $(2,66992 \mathrm{mg} / \mathrm{l})$ dicapai oleh kultur dengan pemberian fotoperiodisitas $24 \mathrm{~T} / 0 \mathrm{G}$.

\section{Daftar Pustaka}

Adil, E.I.M. 2002. Penuntun Praktikum Fisiologi Hewan. Jurusan Biologi. FMIPA UI, Depok. 
Agustini, N.W.S. dan Kabinawa, I.N.K. 1993. Pengaruh Penambahan Nitrogen Terhadap Produksi Biomassa dan Pigmen Chlorella pyrenoidosa dalam skala laboratorium. Prosiding Seminar Nasional Bioteknologi Mikroalga 1993: 151159.

Chrismadha, T., Widiyanto, T., Mardiati, Y. dan Rosidah. 1998. Pengaruh Intensitas Cahaya dan Kepadatan Kultur Terhadap Produktivitas Alga Chlorella sp. Dan Ankistrodesmus convolutus. Hasil Penelitian Puslitbang Limnologi Tahun 1997/1998, Puslitbang Limnologi Lembaga Ilmu Pengetahuan Indonesia, Cibinong: 335-342.

Clegg, C.J. and Mackean, D.G. 2000. Advanced Biology: Principles and Applications. $2^{\text {nd }}$ ed. John Murray Ltd., London.

Fogg, G.E. and Thake, B. 1987. Algal Cultures and Phytoplankton Ecology. $3^{\text {rd }}$ ed. The University of Wisconsin Press, Wisconsin.

Hadiwigeno, S., Cholik, F. dan Sukadi, F. 1993. Peranan Bioteknologi Mikroalga dalam Rangka Menunjang Pengembangan Industri Perikanan. Prosiding Seminar Nasional Bioteknologi Mikroalga 1993: 7-17.

Hase, E. 1962. Cell division. In: Lewin, R.A. (ed.) 1962. Physiology and Biochemistry of Algae. Academic Press, New York.

Hendrayanti, D. 1995. Pengaruh Penambahan Beberapa Konsentrasi Glukosa terhadap Pertumbuhan Chlorella pyrenoidosa Chick dalam Medium Beneck. Skripsi Sarjana Biologi FMIPA-UI, Depok.

Kabinawa, I.N.K. 1993. Kultur Mikroalga: Aspek dan Prospek. Prosiding Seminar Nasional Bioteknologi Mikroalga 1993: 21-43.

Kabinawa, I.N.K., Agustini, N.W.S. dan Adam, I. 1993. Pengaruh Penambahan $\mathrm{N}$ dan $\mathrm{P}$ terhadap Produksi Protein Mikroalga Chlorella pyrenoidosa. Prosiding Seminar Nasional Bioteknoligi Mikroalga 1993: 112-120.

Kaftan, D., Meszaros, T., Whitmarsh, J. and Nedbal, L. 1999. Characterization of Photosystem II Activity and Heterogeneity during the Cell Cyle of the Green Alga Scenedesmus quadricauda. Journal of Plant Physiology 120 (2): 433-441.
Lee, Kwangyong and Lee, Choul-Gyun. 2001. Effect of Light/Dark Cycles on Wastewater Treatments by Microalgae. Biotechnol. Bioprocess Eng. 6(3): 194-199.

Lorenzen, H. 1964. Synchronization of Chlorella with Light-Dark Changes and Periodical Dilution of the Population to a Standard Cell Number. In: Zeuthen, E. (ed.). 1964. Synchrony in Cell Division and Growth. John Wiley \& Sons, Inc., New York.

Madigan, M.T., Partinko, J.M. and Parker, J. 1997. Brock Biology of Microorganism. $8^{\text {th }}$ ed. PrenticeHall, Inc., Englewood Cliff.

Meeks, J.C. 1974. Chlorophylls. Dalam: Stewart, W.D.P. (ed.). 1974. Algal physiology and biochemistry. University of California Press, Los Angeles.

Nichols, H.W. 1973. Growth media freshwater. Dalam: Stein, J.R (ed.). 1973. Handbook of physiological methods, culture methods \& growth measurement. Cambridge University Pres, Cambridge: 7--24.

Ogbonna, J.C., Soejima, T. and Tanaka, H. 1999. An Integrated Solar and Artificial Light System for Internal Illumination of Photobioreactors. Journal of biotechnology 70: 289-297.

Pandey, S.N. and Trivedi P.S. 1995. A Textbook of Algae. Vikas Publishing House PVT. Ltd., New Delhi.

Reynolds, C.S. 1984. The ecology of freshwater phytoplankton. Cambridge University Press, Cambridge.

Sachlan, M. 1982. Planktonologi. Fakultas Peternakan dan Perikanan Universitas Diponegoro, Semarang.

Soeder, C. and Stengel, E. 1974. Physico-chemical Factors Affecting Metabolism and Growth Rate. In: Stewart, W.D.P. (ed.). 1974. Algal Physiology and Biochemistry. Blackwell Scientific Publication, Oxford.

Sze, P. 1993. A Biology of the Algae. $2^{\text {nd }}$ ed. Wm. C. Publishers, Dubuque.

Wirosaputro, S. 1998. Chlorella: Makanan Kesehatan Global Alami. Gadjah Mada University Press. 
